\title{
Overview of Marine Stock Enhancement, Restocking and Sea Ranching in Ghana
}

\author{
Berchie Asiedu, Gyamfua Afriyie and \\ Samuel Kwaku Konney Amponsah \\ Additional information is available at the end of the chapter \\ http://dx.doi.org/10.5772/intechopen.79454
}

\begin{abstract}
Fish stocks in Ghanaian waters are on the decline. There is therefore the need to rebuild the stocks through marine stock enhancement and restocking. Stock enhancement and restocking are the guarantee routes to revive the stock declining menace of the country. Other benefits will include sustainable employment, increase fishers income, reduce poverty, ensures food security and promote national development. Species to be used for restocking is a major problem since the biology of the existing species is poorly understood. There are certain factors that must be taken into considerations if stock enhancement and restock programmes are to be successful, namely existing fisheries management schemes, socio-economic factors, institutional capacity and aquaculture development. The potential for Ghana to create sustainable, supplemental livelihoods through restocking or stock enhancement appears promising.
\end{abstract}

Keywords: Ghana, fish stock, marine resources, fisheries, poverty, sustainability, fisheries management

\section{Introduction}

Fish is an important source of animal protein, omega 3 fatty acids, vitamins (A, B12, D and E), calcium, iodine, iron, selenium and zinc that are often lacking or under-represented in most human diets [1]. Fish is estimated to represent approximately $60 \%$ of average animal protein intake in Ghanaian diet with an average per-capita fish consumption estimated to be $25 \mathrm{~kg}$ in 2014 [2]. The domestic fish supply in Ghana is from the marine, inland, aquaculture and 
imports. Marine accounts for the highest percentage of the production, 70\%; $19 \%$ for inland and $11 \%$ for aquaculture of total fish production in 2016 [3].

Ghana's coast is in the southern part of Gulf of Guinea, spanning an area of $238,500 \mathrm{~km}^{2}$ with a total narrow continental shelf area of about $24,300 \mathrm{~km}^{2}$. The country has an Exclusive Economic Zone (EEZ) of 200 nautical miles (nm), covering an area of 228,509 $\mathrm{km}^{2}$, a territorial sea of $12(\mathrm{~nm})$ and a contiguous zone of $24 \mathrm{~nm}$. The coastline is $550 \mathrm{~km}$ which stretches from Half Assini in the West to Aflao in the East [4, 5].

The Ghanaian fishery sector is important because it generates over US $\$ 1$ billion in revenue each year and accounts for at least $4.5 \%$ of national gross domestic product (GDP) [6]. The sector also provides employment for an estimated 210,000 people work directly in Ghana's fisheries sector, and the sector employs, directly or indirectly, 2.2 million people or $20 \%$ of the population [6]. It also generates income, cheap protein source and supports livelihood.

However, with the exception of the tuna fleet, catch per unit of effort (CPUE) of all fleets has been decreasing. The national statistics indicate a decline from 314,867.57 $\mathrm{mt}$ (2013) to $289,147.23 \mathrm{mt}$ in (2014) [2] due to the unsustainable fishing practices such as fishing with small mesh sized nets, light, chemicals, pollution of the sea, etc. This necessitates the need to revive the fish stock and restore the derived benefits through better fisheries management practice such as stock enhancement, restocking and sea ranching, among others.

The fisheries in Ghana is near collapse. This has resulted in food insecurity, poverty, malnutrition and slow economic growth. Stock enhancement is a common practice in the developed world. However, in Ghana, the Government is not motivated to undertake stock enhancement programmes. The regulations, institution, infrastructure and technology are weak for stock enhancement and restocking programmes. The species to be selected for enhancement, management goals and objectives, assessing stocking effects, dealing with consumers' acceptability as well as economic and social considerations need to be considered.

Restocking Ghanaian fisheries will boost fish production, revenue from fisheries, food security, sustain livelihoods of millions of dependents and bring economic benefits to the country.

\section{The state of fisheries in Ghana}

Ghana has three main fishing units, namely artisanal, semi industrial and industrial. The artisanal fishing sector which comprises of about 9,951 small canoes lands about $70 \%$ of the total annual fish landings (254,000 metric tons) in Ghana. Its main catch composition includes mackerels, sardines and anchovies. The semi industrial which consists of trawlers and purse seiners mostly lands about 6,000 metric tons of fish with sardines and mackerels as its targeted fishes. On the other hand, industrial fishing sector made up of tuna purse seiners, tuna bait and trawl fleet harvest approximately 83,500 metric tons of fishes. Key fish species harvested by these industrial vessels include groupers, cuttlefish, snappers, yellowfin tuna, bigeye tuna and skipjack tuna [3]. Marine capture fisheries supply about 328,541 metric tons of fish annually (Table 1), despite the annual consumption of about 950,000 metric tons by Ghanaians. 


\begin{tabular}{lllllllll}
\hline Year/Fleet & $\mathbf{2 0 0 9}$ & $\mathbf{2 0 1 0}$ & $\mathbf{2 0 1 1}$ & $\mathbf{2 0 1 2}$ & $\mathbf{2 0 1 3}$ & $\mathbf{2 0 1 4}$ & $\mathbf{2 0 1 5}$ & $\mathbf{2 0 1 6}$ \\
\hline Artisanal & 226,755 & 198,152 & 196,200 & $213,451.8$ & $202,601.5$ & $179,686.3$ & $187,401.23$ & $221,355.56$ \\
Inshore & 6140 & 12,048 & 9399 & 9574 & $10,482.33$ & 7254.91 & $11,899.64$ & $12,131.52$ \\
Industrial & 20,837 & 19,673 & 19,597 & $19,763.3$ & $19,406.50$ & $31,562.43$ & $31,560.45$ & $24,780.37$ \\
Tuna & 66,470 & 77,876 & $80,823.0$ & 90,000 & $82,899.03$ & 76,844 & $62,521.27$ & $70,274.03$ \\
Total & 326,109 & 319,331 & 306,194 & $333,697.4$ & $314,867.57$ & 295,361 & $312,535.2$ & $328,541.48$ \\
\hline
\end{tabular}

Source: [3].

Table 1. Marine fish production from 2009 to $2016(\mathrm{mt})$.

To bridge the supply and demand gap, Ghana currently imports over $50 \%$ of its fish, valued at \$135 million worth largely due to reduction in the fish stock, particularly marine fishes [2]. Other notable issues blighting the contribution of marine capture fisheries in Ghana include increased fishing capacity, inadequate regulations and weak enforcement of existing regulations, low level of protection of marine biodiversity and inadequate information on fisheries biology and stocks [2] as well as climate change.

\section{Importance of the fishery resource in national development}

The fisheries sector plays a significant role in the socio-economic development of Ghana. The benefits derive from fisheries as a country is highly significant to the economy. It is evident from key economic indicators such as employment, livelihood support, poverty reduction and food security, particularly in rural fishing communities leading to rural development and the country at large.

\subsection{Food security and protection against malnutrition}

Fish serves as an important source of cheap but quality animal protein, omega 3, fatty acids, vitamins (A, B12, D and E), calcium, iodine, iron, selenium and zinc that are often lacking or under-represented in most human diet [1, 7]. It is consumed in all regions of Ghana, by both the poor and the rich, and in both rural and urban communities. Fish contributes $60 \%$ of annual protein intake of Ghanaians [8].

\subsection{Revenue for the country}

The fisheries sector accounts for about $4.5 \%$ of the GDP and $12 \%$ of the agricultural gross domestic product (AGDP). The marine fisheries sector is estimated to generate approximately US $\$ 1$ billion in total revenue each year $[4,6]$.

\subsection{Employment}

Over 135,000 fishers are directly employed in Ghana's marine capture fisheries and about 2.6 million people rely on them, including spouses, children, close relatives as well as canoe 
carvers, input suppliers and office workers for industrial fishing fleets. Fish workers engaged in processing and distribution alone are estimated to be around 500,000 individuals. Artisanal marine fishers alone number about 120,000 workers. The sector has employed approximately about $10 \%$ of country's labour force [4].

The sector's gender balance is worthy of mention. While men are involved in fishing the actual fishing process, women are engage in postharvest activities such as fish processing, storage and distribution.

\subsection{Poverty reduction}

The sector also supports the livelihoods of $10 \%$ of Ghana's population of about 29 million people [9]. Over 2 million Ghanaians are dependent on the fisheries sector for their livelihoods including some 135,000 fishers in the marine sector alone, of which 124,000 (or 92\%) are artisanal fishers $[10,11]$.

\subsection{Foreign exchange}

Fishery and finfish products are Ghana's most important non-traditional export commodities, accounting for over $50 \%$ of revenue from non-traditional export. About $90 \%$ of tuna landings are exported mainly to EU countries [12]. Tuna sales alone account for $14 \%$ of non-traditional exports (NTEs) from Ghana and are the single largest contributor after horticulture. Fish exports from Ghana are made up of high value tuna (whole, loins and canned), frozen fish (mostly demersal species), shrimps, lobsters, cuttlefish and dried and smoked fish [12].

\section{The current state of fish stocks}

The Ghanaian marine is highly diverse with different valuable fish species ranging from small pelagics such as Round sardinella (Sardinella aurita), Flat sardinella (Sardinella maderensis), Chub-mackerel (Scomber japonicus), Anchovy (Engraulis encrasicolus) and African moonfish (Selene dorsalis) to large pelagics species including Flying gurnard (Dactylopterus volitans), Monrovia doctorfish (Acanthurus monroviae), Triggerfish (Balistes capriscus and Balistes punctatus), Red snapper (Lutjanus fulgens), Red mullet (Pseudupeneus prayensis), Octopus (Octupus vulgaris), shrimps (psenus monodon), Cassavafish (Pseudotolithus brachygnathus), Grouper (Epinephelus goreensis), Dentex (Dentex angolensis) etc. [13].

Other economically valuable fish species that occur in Ghanaian waters are the bigeye tuna (Thunnus obesus), Yellowfin tuna (Thunnus albacares) and skipjack (Katsuwonus pelamis). Tuna is of major commercial importance in Ghana as a result of its export revenues and sustainability, which has been estimated at 100, 000 tonnes annually by the Fisheries Commission. The two tuna species of utmost importance in Ghana's EEZ are skipjack (Katsuwonus pelamis) and yellowfin (Thunnus albacares). Fish are highly exploited especially during the upwelling seasons.

Of these exploited pelagics, the most commercially important in Ghana's coastal fisheries are the anchovies and sardinellas, namely round sardinella (Sardinella aurita) and flat sardinella (S. maderensis) which occur in the entire sea [13]. 


\section{The need for stock enhancement (prospective species)}

Production from marine fisheries has been declining since 2000, from almost 457,000 to 328,000 tonnes in 2016 [3, 13]. In order to sustain the per-capita annual consumption of fish (estimated at around $25 \mathrm{~kg}$ ), imports have increased substantially in the most recent years, reaching USD 373 million in 2013. As a result, the seafood trade balance moved from a USD 33 million surplus in 1997 to a USD 319 million deficit in 2013 [13].

Sizable catches occur only for a period of 3 months (usually July-September) because of seasonal fluctuations in abundance of small pelagic fish species (especially sardinellas); implying that monthly incomes from fishing can be minimal during the rest of the year.

Currently, Ghana's marine stocks are overexploited by the industrial fleet, leading to decline of harvests from marine fisheries. This precipitous decline of Ghana fish stocks has had dire implications for coastal livelihoods which go beyond economic challenges. Locals at the coast use indigenous methods to harvest which is no or less economic intensive during fish abundant seasons.

It is estimated that the fisheries, mostly artisanal, employ over 12,000 fishing vessels, with $70 \%$ motorized [3,13]. This has resulted to increased fishing pressure and high CPUE. The Catch data collated by the Ministry of Fisheries and Aquaculture Development (MoFAD) (2014) indicate a drastic decline of stocks. Recently, the ministry has recorded no catch data of some species indicating full exploited of such species.

It was reported that the total landings of small pelagic (anchovies, sardinellas, mackerels and horse mackerel) have decreased from 277,000 metric tonnes in 1996 to about 92,000 metric tonnes in 2011 [4].

The Ministry is seeking for sustainable ways to restore depleted stocks and increase production to help meet the country's fish deficit, hence the Fisheries and Aquaculture Development Plan has been developed. The potential benefits of this plan include:

- Source as additional catch for commercial and recreational fishermen.

- Rebuild spawning stock biomass for the promotion or acceleration of recovery.

- Ensure the survival of stocks threatened by extinction.

- Mitigate losses due to anthropogenic effects.

\section{The way forward and benefits}

Consequently, declines in fish stocks within Ghana's marine ecosystem will have serious implications on the health and socio-economic of consumers as well as the economy of the nation which jointly depends on contribution of fisheries to the national GDP $(4.5 \%)$. Reduced nutrition particularly in dependent households, increased levels of poverty and loss of jobs for direct and indirect dependents are some of the consequences likely 
to emanate from the current situation - declining fish stocks in Ghana [14]. Collectively, the presence of these consequences limits Ghana's ability to achieve some of the sustainable development goals, particularly SDGs 1, 2 and 14. However, to prevent or minimize the impacts precipitating from declining marine fish species in Ghana, the Ministry of Fisheries and Aquaculture Development (MoFAD) has put in place many measures including increased interest in aquaculture, (the National Committee on Aquaculture has been formed), equipping monitoring, control and surveillance (MCS) section of the Fisheries Scientific and Survey Division with necessary equipment and the establishment of co-management to enhance voluntary compliance to fisheries regulations in Ghana. Nonetheless, the notion of stock enhancement, though, a management tool in fisheries management has not been given the needed attention in the context of Ghanaian fisheries regardless of its success stories in other fishing countries (such as Japan, Australia and USA). For instance, stock enhancement helped to revived Hokkaido Scallop fishery in Japan [15], improved the stocking programmes in Black bream fishery in Australia [16] as well as supported the Coho salmon fishery in Japan [17], which was lost to habitat degradation. Significantly, stock enhancement helps to optimize harvests by overcoming recruitment overfishing to augment the natural supply of juveniles. Though, there are no clear objectives centred on stock enhancement in the MoFAD Management Plan (2015-2019), objectives 2 and 4, which categorically states that (i) to ensure that fish stocks within the marine waters of Ghana are exploited within biologically acceptable levels and (ii) to protect marine habitats and biodiversity provide an opportunity for the application of stock enhancement in Ghana using certain key fish species based on best scientific information available. Nonetheless, for the objectives of stock enhancement to be achieved, certain areas need to be strengthened, for instance, fish stock assessment and modeling, institutional framework, adaptive management, 'clear cut' fishery management perspective and involvement of stakeholders in planning and execution.

Stock enhancement when practiced in Ghana particularly within the marine capture fisheries, which has exhibited gradual decline over the years, will not only ensure that enough fish stock exist for both current and future generations but maintain or increase its contribution to the national economy. Furthermore, the contribution of marine capture fisheries to youth employment will be maintained for decades. However, there is the need to cautiously preserve existing stock while aiming at restoring and increasing the harvest level of these stocks using cultured fishes.

\section{Some critical considerations for marine stock enhancement and restocking in Ghana}

\subsection{Existing fisheries management approach}

The lack of consideration of economic incentives affecting fishermen has resulted in the failure of many fisheries management systems worldwide. There is the need to recognize both the biological and economic realities of fisheries management. 


\subsection{The socio-economic and institutional aspects of stock enhancement and restocking}

In other parts of the world, successful stock enhancement and sea ranching programmes are often run by cooperatives and the private sector $[18,19]$ therefore, involvement of NGOs and other private sector fishery business will go a long way to ensure the revival of the fish stock through sea ranching. This programme can raise awareness of the importance of fishery management among stakeholders, resulting in increased willingness to accept fishing effort controls [20].

\subsection{Aquaculture consideration}

A promising synergy between capture fisheries and aquaculture is the opportunity to apply hatchery technology to restore and augment some coastal fisheries through the release of cultured juveniles [20]. The aquaculture sector in Ghana is developing which currently contribute to $11 \%$ to total fish production [3]. The sector needs to consider mariculture activities, which will be beneficial to stock enhancement and restocking programme in the country.

\section{Conclusion}

Fish stocks in Ghanaian waters are declining. There is therefore the need to urgently rebuild the stocks through marine stock enhancement and restocking. This will ensure sustainable livelihood, increase fisherman's income, reduce poverty, ensures food security and promote national development. Species to be used for restocking is a major problem since the biology of the existing species is poorly understood.

\section{Author details}

Berchie Asiedu*, Gyamfua Afriyie and Samuel Kwaku Konney Amponsah

*Address all correspondence to: berchieasiedu@yahoo.com

Department of Fisheries and Water Resources, School of Natural Resources, University of Energy and Natural Resources, Sunyani, Ghana

\section{References}

[1] Asiedu B, Nunoo FKE, Iddrisu S. Prospects and sustainability of aquaculture development in Ghana, West Africa. Cogent Food and Agriculture. 2017;3:1349531 
[2] Ministry of Fisheries and Aquaculture Development (MoFAD). Annual Report. Accra. 2015. pp. 70

[3] Ministry of Fisheries and Aquaculture Development (MoFAD). Annual Report. Accra. 2017. pp. 78

[4] Ministry of Fisheries and Aquaculture Development (MoFAD). (2014). Fisheries management plan of Ghana; a National Policy for the Management of the Marine Fisheries Sector 2015-2019. MoFAD Accra

[5] Samey B. Literature Review On Sardinella Value Chain. The USAID/Ghana Sustainable Fisheries Management Project (SFMP). Narragansett, RI: Coastal Resources Center, Graduate School of Oceanography, University of Rhode Island and SNV Netherlands Development Organization. GH2014_SCI007_SNV. 2015

[6] World Bank. Revitalizing the Ghanaian Fisheries Sector for Wealth and Sustainability, Scoping Study. 2009

[7] Kawarazuka N, Bene C. The potential role of small fish species in improving micronutrient deficiencies in developing countries: Building evidence. Public Health Nutrition. 2011;14(11):1927-1938

[8] Asiedu B, Failler P, Beyens Y. Enhancing aquaculture development: Mapping the tilapia aquaculture value chain in Ghana. Reviews in Aquaculture. 2016;8(4):394-402

[9] GSS. Ghana Population Projection Census 2018. Accra: GSS; 2018

[10] Tetteh AS. Women Activities in the Ghanaian Fisheries; The Role of Social Capital. International Fisheries Management [M.S. thesis]. University of Tromso. 2007

[11] Asiedu B. An Investigation of Fish Catch and Poverty Levels for Enhanced Management of Small-scale Fisheries of Ghana. PhD Thesis, University of Ghana. 2012. pp 203

[12] Failler P, Asiedu B, Beyens Y. Value chain analysis of the fishery sector in Ghana with focus on quality, environmental, social, sustainable, food safety, organic requirements and its compliance in infrastructure. United Nations Industrial Development Organization Trade Capacity Building for Ghana Project. Contract No. 3000018889. Report number: US/GHA/06/005. 2014. pp. 108. DOI: 10.13140/RG.2.1.2421.5201

[13] FAO. Fishery and Aquaculture Country Profiles: Republic of Ghana. Rome: FAO; 2018. Available from: http://www.fao.org/fishery/facp/GHA/en [Accessed: 21-02-2018]

[14] Asiedu B, Nunoo FKE, Ofori-Danson PK, Sarpong DB, Sumaila UR. Poverty measurements in small-scale fisheries of Ghana: A step towards poverty eradication. Current Research Journal of Social Sciences. 2013;5(3):75-90

[15] Uki N. Stock enhancement of the Japanese scallop Patinopecten yessoensis in Hokkaido. Fisheries Research. 2006;80:62-66

[16] Dibden CJ, Jenkins G, Sarre GA, Lenanton RCJ, Ayvazian SG. The evaluation of a recreational fishing stock enhancement trial of black bream (Acanthopagrus butcheri) in the Swan River, Western Australia. Fisheries Research Report No. 124. 2000. pp. 26 
[17] Kitada S. Japanese chum salmon stock enhancement: Current perspective and future challenges. Fisheries Science. 2014;80:237-249

[18] Arbuckle M. Scallop stock enhancement in New Zealand: Lessons from applying an integrated approach. www.searanching.org/program/ documents/Arbuckle.pdf 2006

[19] Cooper J, Hill J. Enhancement of paua stocks in New Zealand. www.searanching.org/ program/documents/Cooper 000.pdf (abstract) 2006

[20] Bell DJ, Leber MK, Blankenship LH, Loneragan RN, Masuda RA. New era for restocking, stock enhancement and sea ranching of coastal fisheries resources. Reviews in Fisheries Science. 2008;16(1-3):1-9. DOI: 10.1080/10641260701776951 
